\title{
The development of emotional intelligence in adolescence
}

\author{
Igor Esnaola*, Lorena Revuelta, Iker Ros, and Marta Sarasa \\ University of the Basque Country (Universidad del Pais Vasco/Euskal Herriko Unibertsitatea-UPV/EHU-)
}

\begin{abstract}
Title: El desarrollo de la inteligencia emocional durante la adolescencia. Resumen: En este estudio se analizó el desarrollo de las diferentes dimensiones de la inteligencia emocional durante un curso escolar y transversalmente entre los seis cursos analizados en una muestra de 484 adolescentes de ambos sexos, entre $1^{\circ}$ de ESO y $2^{\circ}$ de Bachiller, a quienes se administró la versión en castellano del Emotional Quotient Inventory: Young Version Short (Caraballo y Villegas, 2001). Coincidiendo con el grueso de la investigación previa, los resultados indican que, salvo en lo que respecta a la dimensión manejo del estrés en la muestra femenina, el resto de dimensiones de la inteligencia emocional no experimenta cambios sustantivos en relación con la edad.
\end{abstract}

Palabras clave: Inteligencia emocional; adolescencia; desarrollo.

\section{Introduction}

There has been increasing interest in emotional intelligence (EI) in recent decades within both academic and professional spheres and this has led to the emergence of two different models: the ability model and the trait or mixed models. The ability model defines EI as the ability to process information with emotional content (Mayer \& Salovey, 1997), whereas the mixed models define EI as an array of stable personality traits, social and emotional skills, motivational aspects and different cognitive skills (Bar-On, 2000; Boyatzis, Goleman, \& Rhee, 2000; Goleman, 1995; Petrides \& Furnham, 2003). Among the mixed models, Bar-On (2000, 2006) defines Emotional and Social Intelligence (ESI) as an inter-related array of emotional and social competencies, skills and facilitators which determine how effectively we understand and express ourselves, how we understand others and engage with them, and how we cope with the demands of everyday life. This model is of interest in that it combines the cognitive skills contained in the definitions of EI as an ability with the emotional facets or aptitudes related to EI as a trait.

Regarding EI development, certain studies suggest that age has no significant effect on EI (Cakan \& Altun, 2005). Nevertheless, others have pointed out a direct relationship between age and EI levels; specifically, the older the subject the higher the EI level, which suggests that EI is learnt through life experience (Bar-On, 2000; Goldenberg, Matheson, \& Mantle, 2006; Kafetsios, 2004). For instance, people aged between 40 and 49 score significantly higher for general EI than those in the 20-29 age group (Bar-On, 1997a), and this supports the thesis that EI increases with age. However, other studies conducted with university undergraduates (Benson, Martin, Ploeg, \& Wessel, 2012) only found significant increases in one of the Emotional Quotient Inventory

* Correspondence address [Dirección para correspondencia]: Igor Esnaola, Department of Developmental and Educational Psychology, Faculty of Education, Philosophy and Anthropology, Avda. de Tolosa, 70, 20018. Donostia-San Sebastián (Spain). orcid.org/0000-00024159-3565. E-mail: igor.esnaola@ehu.eus
Abstract: The aim of this study was to analyse the development of the different dimensions of emotional intelligence in adolescents over one school year and in a cross-sectional study involving 484 adolescents of both sexes from the six school years between year 1 of Spanish secondary school (age 12-13) and year 2 of the Spanish Baccalaureate (age 17-18). Participants were administered the Spanish version of the Emotional Quotient Inventory: Young Version Short (Caraballo \& Villegas, 2001). Consistently with most previous research, the findings indicate that, except for the stress management dimension in the female sample group, none of the dimensions of emotional intelligence undergo substantial changes in relation to age.

Key words: Emotional intelligence; adolescence; development. (short) scales, specifically that of adaptability. Consequently, the age / EI relationship may not be linear. Indeed, from an EI study involving Indian executives (Punia, 2002) it could be deduced that while EI levels do indeed increase with age, at some point they peak and start to decline.

There has been growing interest in EI among adolescents over recent years due to evidence from certain studies regarding its importance in early ages for variables such as academic performance (Bar-On, 2003; Ferrando et al., 2010; Parker et al., 2004), social interaction (Bar-On, 1997a), consumption of toxic substances (Limonero, Tomás-Sábado, \& Fernández-Castro, 2006), self-concept (Coelho, Marchante, \& Sousa, 2016) and academic and social adaptation (Mestre, Guil, Lópes, Salovey, \& Gil-Olerte, 2006; Serrano \& Andreu, 2016).

Few studies have focused on EI development in adolescence. Keefer, Holden and Parker (2013), who analysed the psychometric properties of the Emotional Quotient Inventory: Young Version Short (Bar-On \& Parker, 2000) in a Canadian sample of 10-18-year-olds over a six-year period (this was the first study to research longitudinal differences in EI over a period of several years), reported non-variance in three (intrapersonal, interpersonal and adaptability) of the four scales between the ages of 12 and 18. It has not been possible to confirm the longitudinal usefulness of the stress management scale. Regarding changes in accordance with age, the authors state that the findings present a complex panorama, with varying decreasing, increasing and steady patterns depending on age and the different specific scales. For example, between infancy and early adolescence, the intrapersonal and adaptability scales show significant decreases. On the other hand, between early and late adolescence the interpersonal and adaptability scales present significant increases. Regarding the intrapersonal scale there is first a decrease between the $10-11$ and $12-13$ age ranges, followed by relatively little change until the age of 17 . In relation to the interpersonal scale, there is no change between the first two age ranges $(10-11,12-13)$, and subsequently there is an increase. With regard to stress management, there is no change in the first two school years and then a decrease at the age of 15 , after 
which it remains steady from 16-17. Lastly, the adaptability scale decreases until 14-15 and then increases at 16-17; the degrees of change are relatively minor during the six-year time period (Keefer et al., 2013). The increase in emotional competence among older age groups is consistent with the expectation that emotional skills should increase progressively with greater maturity and further life experience (Mayer, Caruso, \& Salovey, 1999; Saarni, 1999). Nonetheless, the decreases in perceived EI among younger age groups contradict the maturity hypotheses, although they are at least in line with those observed for self-perception and selfcompetence in other domains (Jacobs, Lanza, Osgood, Eccles, \& Wigfield, 2002; Marsh, 1989; Wigfield \& Wagner, 2005).

Different variables may influence self-confidence in early adolescence; as children mature cognitively and socially they are able to more realistically self-assess their strengths and weaknesses and become more aware of how they compare with their classmates and peers (Harter, 2012). Adolescents' confidence in their ability to understand and regulate their emotions may also decline in the context of the greater emotional sensitivity which comes with the onset of puberty (Somerville, Jones, \& Casey, 2010). The change from primary school to secondary school may also lead to new demands and expectations which encourage young adolescents to adopt higher standards when assessing their competences (Wigfield \& Wagner, 2005). The accumulation of these influences may result in the decreases observed in emotional perceptions, despite the fact that emotional skills continue to improve in this period. Likewise, it appears to be the case that the different components of EI may develop differently prior to adulthood. Hence, there remain unanswered questions which require further research.

With regard to the influence of sex on EI, most studies appear to point to the existence of certain differences (Joseph \& Newman, 2010; Salguero, Fernández-Berrocal, Balluerka, \& Aritzeta, 2010). Bar-On (1997b) states that women are more emotionally aware, display more empathy and relate better to others, whereas men are better at managing and regulating emotions. Women tend to score higher than men on the interpersonal scale whereas men tend to achieve higher scores for self-perception on the intrapersonal, adaptability and stress management scales (Bar-On, 1997b; Bar-On, Brown, Kirkcaldy, \& Thome, 2000; Ugarriza \& Pajares, 2005). Keefer et al. (2013) found that women score higher on the intrapersonal and interpersonal scales while men score higher for adaptability. In terms of general EI, some studies find that women have better self-perception (Saklofske, Austin, \& Minski, 2003; Van Rooy, Alonso, \& Viswesvaran, 2005), while others maintain that this is the case for men (Kong, Zhao, \& You, 2012; Mikolajczak, Luminet, Lerooy, \& Roy, 2007; Shi \& Wang, 2007). However, FernándezBerrocal, Cabello, Castillo and Extremera (2012) believe that sex differences are mediated by age, so we should therefore be cautious when concluding that sex is a determining varia- ble in EI, unless we have thoroughly analysed potential interaction with other variables.

Hence, given that there are very few studies analysing the development of EI during adolescence, and none at national level in Spain, the aim of this study was to explore the temporary stability of EI over the course of one school year, using cross-sectional sample age groups from across six levels ranging from year 1 of Spanish secondary school (age 12-13) to year 2 of the Spanish Baccalaureate (age 17-18).

\section{Method}

\section{Participants}

Participants in this cross-sectional and longitudinal developmental "ex post facto" study comprised 484 adolescents from public and semi-private schools ${ }^{1} ; 226$ boys $(46.7 \%)$ and 258 girls $(53.3 \%)$. The sample group was drawn from between year 1 of Spanish secondary school (age 1213) and year 2 of the Spanish Baccalaureate (age 17-18). The sample was divided as follows according to school year: Year 1 secondary (Grade 7,n=83), Year 2 secondary (Grade 8, $n=81$ ), Year 3 secondary (Grade 9, $n=88$ ), Year 4 secondary (Grade 10,n=75), Year 1 Baccalaureate (Grade 11, n = 89), and Year 2 Baccalaureate (Grade 12, $n=68$ ). The sampling method used was incidental and data was collected at two different times, at the start of the school year $\left(M_{\text {age }}=\right.$ $14.99, S D=1.81)$; and at the end of the school year $\left(M_{\text {age }}=\right.$ $15.64, S D=1.80)$.

\section{Instruments}

Emotional Intelligence was assessed using the Emotional Quotient Inventory: Young Version Short [EQ-i: YV(s), Bar-On \& Parker, 2000, translated by Caraballo \& Villegas, 2001]. This is a self-test designed to measure the EI of children and adolescents aged between 7 and 18. The test comprises 30 items which rate the dimensions intrapersonal, interpersonal, stress management and adaptability. The results are then added together to give a score for general emotional intelligence. There is also a fifth scale, positive impression, created to measure the extent to which subjects respond randomly or distort their responses as a result of the social desirability bias. As with several previous studies (Hassam \& Sader, 2005; Parker et al., 2005; Sáinz, Ferrándiz, Fernández, \& Ferrando, 2014; Ugarriza \& Pajares, 2005), this fifth scale was not taken into consideration (items 3, 7, 11, 15, 20 and 25) in the presentation of the findings. The questionnaire uses a Likert-type scale with four response options ranging from "very seldom or not true of me" to "very often true of me or true of me" and was recently validated with a Spanish sample (Esnaola, Freeman, Sarasa, Fernández-Zabala, \& Axpe, 2016).

Reliability was measured using Cronbach's alpha, composite reliability (CR) and McDonald's Omega index, an indicator which is less biased than Cronbach's alpha for cate-

${ }^{1}$ Private schools which receive some state funding. 
gorical response scales (Elosua \& Zumbo, 2008). The index values were as follows: interpersonal $(\alpha=.67, \mathrm{CR}=.70$, and McDonald's Omega = .69); intrapersonal $(\alpha=.84$, CR $=.87$, and McDonald's Omega $=.86)$; stress management $(\alpha=.84$, $\mathrm{CR}=.86$, and McDonald's Omega $=.85) ;$ adaptability $(\alpha=$ $.83, \mathrm{CR}=.85$, and McDonald's Omega $=.84)$; and the questionnaire in general $(\alpha=.77, \mathrm{CR}=.95$, and McDonald's Omega $=.95)$.

\section{Procedure}

This study was granted an ethical permit from the Commission for Ethics in Research and Teaching (CEID) at the University of the Basque Country (Universidad del País Vasco/Euskal Herriko Unibertsitatea). After requesting and gaining permission from the participating schools, all families were sent a letter asking for their consent regarding participation in the study. Subsequently, the battery of questionnaires was administered to those students whose families had consented to their participation. This was done during class time and in groups, at two different times: at the start of the school year (September/October, Time 1) and at the end of the school year (May/June, Time 2). During this process, both the anonymity of the responses and voluntary participation were guaranteed.

\section{Data analysis}

Following the use of multiple imputation to replace missing data using the Lisrel 8.8 program (Jöreskog \& Sörbom, 2006), the data gathered were analysed with the
SPSS statistics program for Windows. The Mann-Whitney test was used to compare the findings for the dimensions of emotional intelligence in accordance with sex, due to the fact that the sub-scales did not meet normality requirements. In order to compare the scores in accordance with the two different times, first the differences between the scores obtained at Time 1 and Time 2 were calculated and subsequently, the normality of these differences was estimated. Owing to the fact that there was no normality, the Wilcoxon W test for repeated measurements was used and the Kruskal-Wallis test was employed for the analysis in accordance with school year. The $d$ index (Cohen, 1988) was used to analyse the magnitude of the differences observed (i.e. effect size).

\section{Results}

Due to the fact that previous research points to the possible existence of significant sex-based differences (Bar-On, 1997b; Keefer et al., 2013), the scores obtained were first analysed in order to verify the appropriateness of presenting the subsequent findings either as one whole sample or independently for each sex. The findings indicated that girls scored significantly higher than boys in the interpersonal dimension $\left(z_{(482)}=-5.741, p=.001\right)$, with a medium effect size $(d=-0.39)$. It was therefore decided to present the subsequent findings independently for each sex. Table 1 shows the data pertaining to EI evolution in the male sample over one school year.

Table 1. Longitudinal emotional intelligence scores for boys.

\begin{tabular}{|c|c|c|c|c|c|c|}
\hline & & $\begin{array}{l}M(S D) \\
\text { Time } 1\end{array}$ & $\begin{array}{l}M(S D) \\
\text { Time } 2\end{array}$ & $z(d f)$ & $p$ & $d$ \\
\hline & Intrapersonal & $13.58(4.18)$ & $14.29(4.52)$ & $-1.185(45)$ & .236 & -0.16 \\
\hline Grade 7 & Interpersonal & $17.17(3.13)$ & $17.48(2.60)$ & $-.530(45)$ & .596 & -0.10 \\
\hline \multirow[t]{3}{*}{$(n=46)$} & Stress management & $15.48(4.58)$ & $15.23(4.22)$ & $.366(45)$ & .714 & 0.05 \\
\hline & Adaptability & $16.45(4.09)$ & $17.15(3.98)$ & $-1.240(45)$ & .215 & -0.17 \\
\hline & Intrapersonal & $13.96(4.62)$ & $14.68(3.94)$ & $-.952(46)$ & .341 & -0.16 \\
\hline Grade 8 & Interpersonal & $18.52(3.04)$ & $18.75(3.01)$ & $-.487(46)$ & .626 & -0.07 \\
\hline \multirow[t]{3}{*}{$(n=47)$} & Stress management & $16.08(4.75)$ & $16.28(4.10)$ & $-.349(46)$ & .727 & -0.04 \\
\hline & Adaptability & $15.87(4.30)$ & $16.58(3.96)$ & $-1.228(46)$ & .220 & -0.17 \\
\hline & Intrapersonal & $14.61(4.08)$ & $13.88(4.07)$ & $-1.505(43)$ & .132 & 0.17 \\
\hline Grade 9 & Interpersonal & $18.03(2.65)$ & $18.13(2.46)$ & $-.327(43)$ & .744 & -0.03 \\
\hline \multirow[t]{3}{*}{$(n=44)$} & Stress management & $17.45(4.12)$ & $16.89(4.02)$ & $-1.132(43)$ & .258 & 0.13 \\
\hline & Adaptability & $15.75(3.59)$ & $16.14(3.58)$ & $-1.015(43)$ & .310 & -0.10 \\
\hline & Intrapersonal & $12.06(3.79)$ & $12.66(3.30)$ & $-.854(28)$ & .393 & -0.16 \\
\hline \multirow{4}{*}{$\begin{array}{l}\text { Grade } 10 \\
(n=29)\end{array}$} & Interpersonal & $18.48(2.86)$ & $18.48(2.67)$ & $-.487(28)$ & .627 & 0 \\
\hline & Stress management & $16.49(4.20)$ & $16.53(4.79)$ & $-.097(28)$ & .922 & -0.08 \\
\hline & Adaptability & $15.09(2.94)$ & $15.85(4.25)$ & $-1.611(28)$ & .107 & -0.20 \\
\hline & Intrapersonal & $13.88(4.32)$ & $14.49(4.75)$ & $-1.411(39)$ & .158 & -0.13 \\
\hline \multirow{4}{*}{$\begin{array}{c}\text { Grade } 11 \\
(n=40)\end{array}$} & Interpersonal & $18.86(3.14)$ & $17.71(3.03)$ & $-2.608(39)$ & .009 & 0.37 \\
\hline & Stress management & $17.08(3.82)$ & $17.75(4.09)$ & $-1.425(39)$ & .154 & -0.16 \\
\hline & Adaptability & $17.08(2.90)$ & $16.70(2.95)$ & $-.874(39)$ & .382 & 0.12 \\
\hline & Intrapersonal & $12.92(3.49)$ & $12.68(4.32)$ & $-.224(19)$ & .823 & 0.06 \\
\hline \multirow{3}{*}{$\begin{array}{l}\text { Grade } 12 \\
(n=20)\end{array}$} & Interpersonal & $17.90(3.15)$ & $19.14(2.37)$ & $-2.053(19)$ & .040 & -0.44 \\
\hline & Stress management & $18.53(4.29)$ & $17.79(4.10)$ & $-1.381(19)$ & .167 & 0.17 \\
\hline & Adaptability & $15.38(3.91)$ & $16.69(3.59)$ & $-2.091(19)$ & .037 & -0.34 \\
\hline
\end{tabular}

Note. Time 1 = September/October; Time 2 = May/June. 
As Table 1 demonstrates, significant differences were observed on the interpersonal scale for Grade 11 (z/39) = 2.608, $p=.009, d=0.37$ ) with a decrease between the start and the end of the school year; significant differences were also found on the interpersonal (z/19) $=-2.053, p=.040, d=$ $0.44)$ and adaptability $\left(z_{(19)}=-2.091, p=.037, d=-0.34\right)$ scales for Grade 12, with a significant increase between the start and the end of the school year in both cases. Aside from this, however, it appears that EI levels over one year for all of the different school age groups are relatively homogeneous, with slight increases, decreases or plateaus depending on the EI element and the school age group. Table 2 below shows the findings for the female sample.

Table 2. Longitudinal emotional intelligence scores for girls.

\begin{tabular}{|c|c|c|c|c|c|c|}
\hline & & $\begin{array}{l}M(S D) \\
\text { Time } 1\end{array}$ & $\begin{array}{l}M(S D) \\
\text { Time } 2\end{array}$ & $z(d f)$ & $p$ & $d$ \\
\hline & Intrapersonal & $14.21(4.64)$ & $13.22(5.27)$ & $-1.199(36)$ & .230 & 0.19 \\
\hline Grade 7 & Interpersonal & $19.45(2.95)$ & $20.43(2.60)$ & $-2.014(36)$ & .044 & -0.35 \\
\hline \multirow[t]{3}{*}{$(n=37)$} & Stress management & $18.55(3.45)$ & $17.51(3.98)$ & $-2.029(36)$ & .042 & 0.27 \\
\hline & Adaptability & $15.23(4.20)$ & $16.31(4.53)$ & $-1.818(36)$ & .069 & -0.24 \\
\hline & Intrapersonal & $13.78(4.32)$ & $14.29(4.58)$ & $-.282(33)$ & .778 & -0.11 \\
\hline Grade 8 & Interpersonal & $19.62(2.61)$ & $20.41(2.37)$ & $-1.718(33)$ & .086 & -0.31 \\
\hline \multirow[t]{3}{*}{$(n=34)$} & Stress management & $16.56(5.03)$ & $15.73(4.91)$ & $-1.359(33)$ & .174 & 0.16 \\
\hline & Adaptability & $15.36(3.61)$ & $16.54(3.16)$ & $-2.590(33)$ & .010 & -0.34 \\
\hline & Intrapersonal & $13.37(4.73)$ & $13.94(4.42)$ & $-.373(43)$ & .709 & -0.12 \\
\hline Grade 9 & Interpersonal & $20.19(3.16)$ & $20.08(2.54)$ & $-.315(43)$ & .753 & 0.03 \\
\hline \multirow[t]{3}{*}{$(n=44)$} & Stress management & $16.18(4.37)$ & $15.63(4.79)$ & $-1.214(43)$ & .225 & 0.11 \\
\hline & Adaptability & $16.16(4.08)$ & $15.97(3.54)$ & $-.093(43)$ & .926 & 0.04 \\
\hline & Intrapersonal & $13.92(4.13)$ & $13.89(3.53)$ & $-.060(45)$ & .952 & 0.07 \\
\hline \multirow{4}{*}{$\begin{array}{c}\text { Grade } 10 \\
(n=46)\end{array}$} & Interpersonal & $19.44(2.61)$ & $19.73(2.75)$ & $-.825(45)$ & .409 & -0.10 \\
\hline & Stress management & $15.90(4.38)$ & $14.87(4.16)$ & $-1.087(45)$ & .277 & 0.24 \\
\hline & Adaptability & $15.73(3.76)$ & $15.88(3.79)$ & $-.224(45)$ & .823 & -0.03 \\
\hline & Intrapersonal & $13.46(4.42)$ & $14.12(4.44)$ & $-1.278(48)$ & .201 & -0.14 \\
\hline \multirow{4}{*}{$\begin{array}{c}\text { Grade } 11 \\
(n=49)\end{array}$} & Interpersonal & $19.41(2.49)$ & $19.49(2.27)$ & $-.035(48)$ & .972 & -0.03 \\
\hline & Stress management & $16.95(4.58)$ & $16.64(4.56)$ & $-.612(48)$ & .541 & 0.06 \\
\hline & Adaptability & $15.38(3.15)$ & $15.34(3.11)$ & $-.264(48)$ & .792 & 0.01 \\
\hline & Intrapersonal & $12.90(3.92)$ & $12.56(4.20)$ & $-.708(47)$ & .479 & 0.08 \\
\hline \multirow{3}{*}{$\begin{array}{c}\text { Grade } 12 \\
(n=48)\end{array}$} & Interpersonal & $20.21(2.49)$ & $20.13(2.29)$ & $-.277(47)$ & .782 & 0.03 \\
\hline & Stress management & $15.23(4.28)$ & $14.97(4.50)$ & $-.872(47)$ & .383 & 0.05 \\
\hline & Adaptability & $16.08(3.04)$ & $16.42(3.31)$ & $-.841(47)$ & .400 & -0.10 \\
\hline
\end{tabular}

Note. Time 1 = September/October; Time 2 = May/June.

The findings for the female sample confirmed significant differences in the interpersonal $\left(z_{(36)}=-2.014, p=.044, d=\right.$ $-0.35)$ and stress management $(z(36)=-2.029, p=.042, d=0.27)$ scales for Grade 7. However, whereas perception of the interpersonal dimension increases in the period between the start and the end of the school year, the perception of stress management decreases over the same time period. For their part, girls from Grade 8 scored higher for perception of adaptability at the end of the school year $(z / 33)_{(33)}=-2.590, p=$ $.010, d=-0.34)$. Consequently, with the exception of the aforementioned cases, it appears that the EI levels among girls over one school year and in all the different age groups are relatively homogeneous or stable, with slight increases, decreases or plateaus depending on the EI element and the age group in question.

Following the analysis of the repeated measurements over the course of one school year, below are the findings of the cross-sectional analysis of all six age groups participating in the study, with the male sample results first.

$\underline{\text { Table 3. Cross-sectional emotional intelligence scores for boys. }}$

\begin{tabular}{|c|c|c|c|c|c|c|}
\hline & & Grade $7(n=46)$ & Grade $8(n=47)$ & Grade $9(n=44)$ Grade $10(n=29)$ & Grade $11(n=40)$ & Grade $12(n=20)$ \\
\hline \multirow{2}{*}{ Intrapersonal } & $M(S D)$ & $13.58(4.18)$ & $13.96(4.62)$ & $14.61(4.08) \quad 12.06(3.79)$ & $13.88(4.32)$ & $12.92(3.49)$ \\
\hline & $\chi^{2}(p)$ & & & $\chi_{(5)}^{2}=6.708(p=.243)$ & & \\
\hline \multirow{2}{*}{ Interpersonal } & $M(S D)$ & $17.17(3.13)$ & $18.52(3.04)$ & $18.03(2.65) \quad 18.48(2.86)$ & $18.86(3.14)$ & $17.90(3.15)$ \\
\hline & $\chi^{2}(p)$ & & & $\chi_{(5)}^{2}=6.261(p=.282)$ & & \\
\hline \multirow{2}{*}{ Stress managemen } & $M(S D)$ & $15.48(4.58)$ & $16.08(4.75)$ & $17.45(4.12) \quad 16.49(4.20)$ & $17.08(3.82)$ & $18.53(4.29)$ \\
\hline & $\chi^{2}(p)$ & & & $\chi_{(5)}^{2}=8.842(p=.116)$ & & \\
\hline \multirow{2}{*}{ Adaptability } & $M(S D)$ & $16.45(4.09)$ & $15.87(4.30)$ & $15.75(3.59) \quad 15.09(2.94)$ & $17.08(2.90)$ & $15.38(3.91)$ \\
\hline & $\chi^{2}(p)$ & & & $\chi^{2}(5)=9.767(p=.082)$ & & \\
\hline
\end{tabular}


As shown in Table 3, no inter-group differences were found in the male sample for any of the four dimensions of
EI. Table 4 shows the cross-sectional findings for the female sample.

Table 4. Cross-sectional emotional intelligence scores for girls.

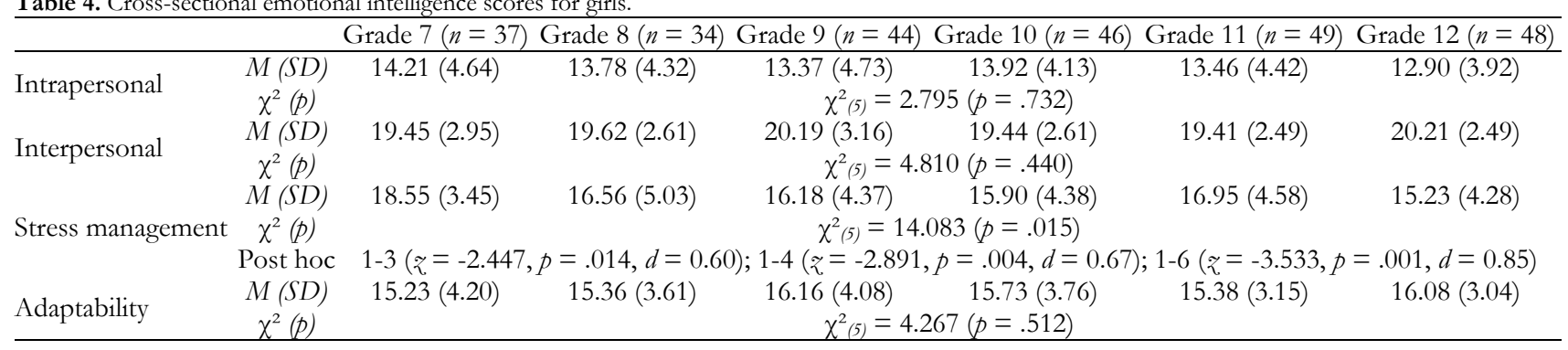

The findings for girls indicate significant inter-group differences only in the stress management dimension $\left(\chi^{2}(5)=\right.$ 14.083, $p=.015$ ), with a downward trajectory between Grade 7 and Grade 12. The post hoc analysis revealed significant differences between Grade 7 and Grade $9(z=$ -2.447, $p=.014, d=0.60)$; between Grade 7 and Grade 10 $(z=-2.891, p=.004, d=0.67)$; and between Grade 7 and Grade $12(z=-3.533, p=.001, d=0.85)$, with girls from Grade 7 scoring consistently higher. The intrapersonal, interpersonal and adaptability dimensions had a relatively flat or stable trajectory, although in the intrapersonal dimension the trend was downward.

\section{Discussion}

The aim of this study was to analyse the development of the different dimensions of EI in a sample of adolescents of both sexes, drawn from a cross-section of pupils from the different year groups of Spanish Secondary School (ages 1216) and Spanish Baccalaureate (17-18), using repeated measurements over one school year (this was the first research study of its kind undertaken at a national level in Spain).

The findings reveal differences between boys and girls in the interpersonal dimension, with girls scoring higher than boys. These findings coincide with most previous research (Bar-On, 1997b; Bar-On et al., 2000; Joseph \& Newman, 2010; Keefer et al., 2013; Salguero et al., 2010; Ugarriza \& Pajares, 2005). It seems that adolescent girls often demonstrate greater ability in certain competences, including those involving mainly interpersonal aspects (Qualter, Gardner, Pope, Hutchinson, \& Whitely, 2012). In other words, most studies suggest the presence of more developed traits or abilities depending on whether the subject is male or female (Caballero, 2004), mostly owing to sex differences in the socialisation and emotional education of boys and girls (Fivush, Brotman, Buckner, \& Goodman, 2000).

Regarding EI development, it should be noted that very little research has been conducted on patterns of continuity and change. In this study, there was little substantial change in self-perception over the time period analysed among any of the age groups studied, which suggests that one school year is not a sufficiently long time period for significant vari- ations in EI to occur among adolescents. In the male sample, differences were found only in the interpersonal dimension in Grade 11 (decreasing between the start and the end of the school year) and Grade 12 (increasing between the start and the end of the school year); and in adaptability in the Grade 12 sample, in which adaptive capacity was observed to increase significantly between the start and the end of the school year. In the female sample, differences were found in the interpersonal and stress management dimensions among Grade 7 pupils, and in adaptability in Grade 8, with a decrease in stress management levels being recorded despite increases in the interpersonal and adaptability dimensions.

As far as the cross-sectional analysis is concerned, it should be highlighted that significant statistical differences were found only in the stress management dimension among girls, with a significant decrease being observed between Grade 7 and Grade 12, with a large effect size. All these findings are consistent with those reported in the study by Keefer et al. (2013), which highlights the relative stable development of certain EI dimensions during adolescence.

Nevertheless, while not statistically significant, the results observed for the stress management scale are interesting, since they follow a different pattern in each sex. In boys, there was an upward "development", with the Grade 7 age group scoring lowest and the Grade 12 age group scoring highest. These findings coincide with the expectation that emotional skills should increase progressively as adolescents mature (Bar-On, 2006; Bar-On \& Parker, 2000; Extremera, Fernández-Berrocal, \& Salovey, 2006; Mayer et al., 1999; Saarni, 1999; Shutte, Malouff, Thorsteinsson, Bhullar, \& Rooke, 2007). However, among the girls in our study, the "evolution" of stress management was completely different from that of boys, decreasing between Grade 7 and Grade 12. These findings, as observed in other studies and in self-perception and self-competence beliefs (Jacobs et al., 2002; Wigfield \& Wagner, 2005), contradict maturity hypotheses. This decrease could be explained by cognitive and social maturity, which enables adolescent girls to more realistically self-assess their strengths and weaknesses, thus rendering them more self-aware (Harter, 2012).

In sum, we may conclude that EI "development" varies in accordance with sex and the dimension being analysed. 
This is consistent with that postulated by Keefer et al. (2013) in their study conducted on adolescents over a six-year period, which found a similar pattern of evolution with increases, decreases and plateaus. Except for the case of the stress management dimension among girls, there was no substantial change in the other dimensions, coinciding with most previous research which reports either little or no differences in EI in accordance with age (Balci-Celik \& Deniz, 2008; Birks, McKendree, \& Watt, 2009; Harrod \& Sheer, 2005; Nasir \& Masrur, 2010); significant albeit relatively weak increases in EI parallel to the developmental process (Fariselli, Ghini, \& Freedman, 2006); or, similarly to that found here, inconsistent and/or inconclusive patterns (Ugarriza \& Pajares, 2005).

As a result of the findings presented here, it could be concluded that there may be other factors with more relevant effects than age, such as education, experience or socialisation in different roles or behaviours, which would explain any possible fluctuations in EI among adolescents. Although age is often associated with higher levels of EI, it is very likely that this has more to do with an accumulation of life experiences rather than the development of EI itself. Hence, there would be subjects of different ages with different EI levels, making it necessary to observe not the cross-

\section{References}

Balci-Celik, S., \& Deniz, M. E. (2008). A comparison of scouts' emotional intelligence levels with regards to age and gender variables: A crosscultural study. Elementary Education Online, 7(2), 376-383.

Bar-On, R. (1997a). Emotional Quotient Inventory: Technical manual. Toronto: Multi-Health Systems.

Bar-On, R. (1997b). Development of the Bar-On EQ-I: A measurement of emotional and social intelligence. Paper presented at the $105^{\text {th }}$ Annual Convention of the American Psychological Association. Chicago.

Bar-On, R. (2000). Emotional and social intelligence. Insights from the Emotional Quotient Inventory. In R. Bar-On \& J. D. A. Parker (Eds.), The handbook of emotional intelligence (pp. 363-388). San Francisco: JosseyBass.

Bar-On, R. (2003). How important is it to educate people to be emotionally and socially intelligent, and can it be done? Perspectives in Education, 21, 313.

Bar-On, R. (2006). The Bar-On model of emotional-social intelligence. Psicothema, 18, 13-25.

Bar-On, R., Brown, J. M., Kirkcaldy, B. D., \& Thome, E. P. (2000). Emotional expression and implications for occupational stress: An application of the Emotional Quotient Inventory (EQ-I). Personality and Individual Differences, 28, 1107-1118. http://dx.doi.org/10.1016/S01918869(99)00160-9

Birks Y., McKendree J., \& Watt I. (2009). Emotional intelligence and perceived stress in healthcare students: A multi-institutional, multiprofessional survey. BMC Medical Education, 9-61. http://dx.doi.org/10.1186/1472-6920-9-61

Bar-On, R., \& Parker, J. D. A. (2000). The Bar-On Emotional Quotient Inventory: Youth Version (EQ-i:YV). Technical Manual (translated to Spanish by C. M. Caraballo y O. Villegas). Toronto, Canada: Multi-Health Systems, Inc.

Benson, T., Martin, L., Ploeg, J., \& Wessel, J. (2012). Longitudinal study of emotional intelligence, leadership, and caring in undergraduate nursing students. Journal of Nursing Education, 51(2), 95-101. http://dx.doi.org/10.3928/01484834-20120113-01

Boyatzis, R. E., Goleman, D., \& Rhee, K. (2000). Clustering competence in emotional intelligence: Insights from the Emotional Competence In- sectional differences between subjects but rather their longitudinal trajectories and, more specifically, the effect of environmental factors on the acquisition of a series of skills of unquestionable importance for psychological adjustment and well-being.

This study has certain limitations. Firstly, the sample group is fairly small. Secondly, it appears that studying EI development over the course of one school year is not sufficient to understand the evolution of this construct in adolescence. Consequently, future research should both increase the analysis period and employ more than two repeated measurements in order to collect more conclusive data. Nonetheless, given that this is the first Spanish study conducted at a national level using two repeated measures, it may prove to be a turning point, encouraging future longitudinal studies analysing EI development over a longer time period.

Acknowledgments.- This study forms part of the research project "Engagement in physical activity: contextual and personal factors" EHU 14/10. Financial support for the project is provided by the University of the Basque Country (Spain). The authors also form a part of the Consolidate Group of Investigation IT934-16 of the University Basque System. ventory (ECI). In R. Bar-On \& J. D. A. Parker (Eds.), Handbook of emotional intelligence (pp. 343-362). San Francisco: Jossey-Bass.

Caballero, A. (2004). Cómo enfocar la educación emocional dentro del aula desde la perspectiva de género. In A.A.V.V., Actas de la Conferencia Internacional de Orientación, Inclusión Social y Desarrollo de la Carrera (pp. 546550). Universidad de la Coruña.

Cakan, M., \& Altun, S. A. (2005). Adaptation of an emotional intelligence scale for Turkish educators. International Education Journal, 6(3), 367-372.

Coelho, V. A., Marchante, M., \& Sousa, V. (2016). Positive attitude program's impact upon self-concept across childhood and adolescence. Revista de Psicodidáctica, 21(2), 261-280. http://dx.doi.org/ 10.1387/RevPsicodidact.15129

Cohen, J. (1988). Statistical power analysis for the behavioral sciences (2nd ed.). Hillsdale, NJ: Lawrence Earlbaum Associates.

Elosua, P., \& Zumbo, B. D. (2008). Coeficientes de fiabilidad para escalas de respuesta categórica ordenada. Psicothema, 20, 896-901.

Esnaola, I., Freeman, J., Sarasa, M., Fernández-Zabala, A., \& Axpe, A. (2016). Validity evidence based on internal structure of scores of the Emotional Quotient-Inventory: Youth Version Short (EQ-i: YV-S) in a Spanish Sample. The Spanish Journal of Psychology, 19, 1-9. http://dx.doi.org/10.1017/sjp.2016.12

Extremera, N., Fernández-Berrocal, P., \& Salovey, P. (2006). Spanish version of the Mayer-Salovey-Caruso Emotional Intelligence Test (MSCEIT) version 2.0: reliabilities, age and gender differences. Psicothema, 18, 42-48.

Fariselli, L., Ghini, M., \& Freedman, J. (2006). Emotional intelligence and age. Retrieved on 1 February 2007 from http://www.6seconds.org/sei/ wp-age.php

Fernández-Berrocal, P., Cabello, R., Castillo, R., \& Extremera, N. (2012). Gender differences in emotional intelligence: The mediating effect of age. Behavioral Psychology/Psicología Conductual, 20(1), 77-89.

Ferrando, M., Prieto, M. D., Almeida, L., Ferrándiz, C., Bermejo, M. R., López-Pina, J. A.,... Fernández, M. C. (2010). TEIQue-ASF and academic performance: A study with adolescents. Journal of Psychoeducational Assessment, 29(2), 150-159. http://dx.doi.org/10.1177/0734282910374707 
Fivush, R., Brotman, M. A., Buckner, J. P., \& Goodman, S. H. (2000). Gender differences in parent-child emotion narratives. Sex Roles, 42, 233253. http://dx.doi.org/10.1023/A:1007091207068

Goldenberg, I., Matheson, K., \& Mantle, J. (2006). The assessment of emotional intelligence: A comparison of performance-based and self-report methodologies. Journal of Personality Assessment, 86(1), 33-45. http://dx.doi.org/10.1207/s15327752jpa8601_05

Goleman, D. (1995). Emotional intelligence. New York, NY: Bantam.

Harrod, N. R., \& Sheer, S. D. (2005). An exploration of adolescent emotional intelligence in relation to demographic characteristics. Adolescence, 40, 503-512.

Harter, S. (2012). Construction of the self: Developmental and sociocultural foundations. New York, NY: Guilford Press.

Hassan, K., \& Sader, M. (2005). Adapting and validating the Baron EQ-I: $\mathrm{YV}$ in the Lebanese context. International Journal of Testing, 5, 301-317. http://dx.doi.org/10.1207/s15327574ijt0503_7

Jacobs, J. E., Lanza, S., Osgood, D. W., Eccles, J. S., \& Wigfield, A. (2002). Changes in children's self-competence and values: Gender and domain differences across grades one through twelve. Child Development, 73, 509527. http://dx.doi.org/10.1111/1467-8624.00421

Jöreskog, K. G., \& Sörbon, D. (2006). LISREL 8.8 for Windows Computer Software]. Lincolnwood, IL: Scientific Software International, Inc.

Joseph, D. L., \& Newman, D. A. (2010). Emotional Intelligence: An integrative meta-analysis and cascading model. Journal of Applied Psychology, 95, 54-78. http://dx.doi.org/10.1037/a0017286

Kafetsios, K. (2004). Attachment and emotional intelligence abilities across the life course. Personality and Individual Differences, 37, 129-145. http://dx.doi.org/10.1016/j.paid.2003.08.006

Keefer, K. V., Holden, R. R., \& Parker, J. D. A. (2013). Longitudinal assessment of trait emotional intelligence. Measurement invariance and construct continuity from late childhood to adolescence. Psychological Assessment, 25(4), 1255-1272. http://dx.doi.org/10.1037/a0033903

Kong, F., Zhao, J., \& You, X. (2012). Social support mediates the influence of emotional intelligence on mental distress and life satisfaction in Chinese young adults. Personality and Individual Differences, 53, 513-517. http://dx.doi.org/10.1016/j.paid.2012.04.021

Limonero, J. T., Tomás-Sábado, J., \& Fernández-Castro, J. (2006). Perceived emotional intelligence and its relation to tobacco and cannabis use among university students. Psicothema, 18, 95-100.

Marsh, H. W. (1989). Age and sex effects in multiple dimensions of selfconcept: Preadolescence to early adulthood. Journal of Educational Psychology, 81, 417-430. http://dx.doi.org/10.1037/0022-0663.81.3.417

Mayer, J. D., Caruso, D. R., \& Salovey, P. (1999). Emotional intelligence meets traditional standards for intelligence. Intelligence, 27, 267-298. http://dx.doi.org/10.1016/S0160-2896(99)00016-1

Mayer, J. D., \& Salovey, P. (1997). What is emotional intelligence? In P. Salovey, \& D. Sluyter (Eds.), Emotional development and emotional intelligence: Implications for educators (pp. 3-31). Nueva York: Basic Books.

Mestre, J. M., Guil, R., Lopes, P. N., Salovey, P., \& Gil-Olarte, P. (2006). Emotional intelligence and social and academic adaptation to school. Psicothema, 18, 112-117.

Mikolajczak, M., Luminet, O., Leroy, C., \& Roy, E. (2007). Psychometric properties of the trait emotional intelligence questionnaire: Factor structure, reliability, construct, and incremental validity in a French-speaking population. Journal of Personality Assessment, 88(3), 338-353. http://dx.doi.org/10.1080/00223890701333431

Nasir, M., \& Masrur, R. (2010). An exploration of emotional intelligence of the students of IIUI in relation to gender, age and academic achievement. Bulletin of Education and Research, 32(1), 37-51.

Parker, J. D. A., Creque, R. E., Barnhart, D. L., Harris, J. I., Majeski, S. A., Wood, L. M.,... Hogan, M. J. (2004). Academic achievement in high school: Does emotional intelligence matter? Personality and Individual Differences, 37, 1321-1330. http://dx.doi.org/10.1016/j.paid.2004.01.002

Parker, J. D. A., Saklofske, D. H., Shaughnessy, P. A., Huang, S. H. S., Wood, L. M., \& Eastabrook, J. M. (2005). Generalizability of the emotional intelligence construct: A cross-cultural study of North American aboriginal youth. Personality and Individual Differences, 39, 215-227. http://dx.doi.org/10.1016/j.paid.2005.01.008

Petrides, K. V., \& Furnham, A. (2003). Trait emotional intelligence: Behavioural validation in two studies of emotion recognition and reactivity to mood induction. European Journal of Personality, 17(1), 39-57. http://dx.doi.org/10.1002/per.466

Punia, B. K. (2002). Emotional intelligence and leadership behavior in Indian executives: An exploratory study. Unpublished manuscript. Hisar: Guru Jambheshwar University.

Qualter, P., Gardner, K. J., Pope, D. J., Hutchinson, J. M., \& Whiteley, H. E. (2012). Ability emotional intelligence, trait emotional intelligence, and academic success in British secondary schools: A 5 year longitudinal study. Learning and Individual Differences, 22(1), 83-91. http://dx.doi.org/10.1016/j.lindif.2011.11.007

Saarni, C. (1999). The development of emotional competence. New York, NY: Guilford Press.

Sáinz, M., Ferrándiz, C., Fernández, C., \& Ferrando, M. (2014). Propiedades psicométricas del Inventario de Cociente Emocional EQ-i: YV en alumnos superdotados y talentosos. Revista de Investigación Educativa, 32(1), 41-55. http://dx.doi.org/10.6018/rie.32.1.162501

Saklofske, D. H., Austin, E. J., \& Minski, R. S. (2003). Factor structure and validity of a trait emotional intelligence measure. Personality and Individual Differences, $\quad 34, \quad 707-721 . \quad$ http://dx.doi.org/10.1016/S01918869(02)00056-9

Salguero, J. M., Fernández-Berrocal, P., Balluerka, N., \& Aritzeta, A. (2010). Measuring perceived emotional intelligence in adolescent population: Psychometric properties of the Trait Meta Mood Scale. Social Behavior and Personality, 38(9), http://dx.doi.org/10.2224/sbp.2010.38.9.1197

Schutte, N. S., Malouff, J. M., Thorsteinsson, E. B., Bhullar, N., \& Rooke, S. E. (2007). A meta-analytic investigation of the relationship between emotional intelligence and health. Personality and Individual Differences, 42(6), 921-933. http://dx.doi.org/10.1016/j.paid.2006.09.003

Serrano, C., \& Andreu, Y. (2016). Inteligencia emocional percibida, bienestar subjetivo, estrés percibido, engagement y rendimiento académico en adolescentes. Revista de Psicodidáctica, 21(2), 357-374. http://dx.doi.org/10.1387/RevPsicodidact.14887

Shi, J., \& Wang, L. (2007). Validation of emotional intelligence scale in Chinese university students. Personality and Individual Differences, 43, 377-387. http://dx.doi.org/10.1016/j.paid.2006.12.012

Somerville, I. H., Jones, R. M., \& Casey, B. J. (2010). A time of change: Behavioral and neural correlates of adolescent sensitivity to appetitive and aversive environmental cues. Brain and Cognition, 72, 124-133. http://dx.doi.org/10.1016/j.bandc.2009.07.003

Ugarriza, N., \& Pajares, L. (2005). La evaluación de la inteligencia emocional a través del inventario de Bar-On ICE: NA, en una muestra de niños y adolescentes. Persona, 8, 11-58.

Van Rooy, D., L., Alonso, A. B., \& Viswesvaran, C. (2005). Group differences in emotional intelligence scores: Theoretical and practical implications. Personality and Individual Differences, 38, 689-700. http://dx.doi.org/10.1016/j.paid.2004.05.023

Wigfield, A., \& Wagner, A. (2005). Competence, motivation, and identity development during adolescence. In A. J. Elliot \& C. S. Dweck (Eds.), Handbook of competence and motivation (pp. 222-239). New York, NY: Guilford Press.

(Article received: 24-06-2016; revised: 26-06-2016; accepted: 27-09-2016) 